\title{
STEARIC ACID MODIFIED ALUMINUM ALLOY 5556
}

\author{
Anastasiya SPIRIDONOVA, Aleksey ABRASHOV, Nelya GRIGORYAN, Kristina BESSONOVA, \\ Tigran VAGRAMYAN, Yan TOLMACHYOV
}

\author{
MUCTR - D.Mendeleev University of Chemical Technology of Russia, Moscow, Russian Federation, \\ anmalenkova1@gmail.com
}

https://doi.org/10.37904/metal.2019.893

\begin{abstract}
One of the methods of protection of metal surfaces from an aggressive environment is the formation of continuous coating on their surfaces with water-repelling properties and a self-cleaning ability, which give the material superhydrophobic properties and also protect them from contamination.

A solution for hydrophobization of aluminum alloy 5556 in a solution containing dimethyl sulfoxide and water in a ration of 7:1 and also stearic acid in the amount of $0.01 \mathrm{~mol} / \mathrm{L}$ was developed.

It was determined that the newly-formed coating in this solution is characterized by a contact angle of $\theta_{\mathrm{c}}=151^{\circ}$. The protective ability of coatings determined by the drop method as the time until the appearance of corrosion product under the drop of Akimov solution amounts to $125 \mathrm{~s}$.

Corrosion tests of AA 5556 speciments with hydrophobized surface were conducted (ASTM B117) in a salt fog chamber in the developed solution. The tests have shown that the developed coating withstands $140 \mathrm{~h}$ in salt fog conditions $(5 \% \mathrm{NaCl})$ until the appearance of corrosion hotbeds on the base, while the unprocessed specimen of aluminium alloy started corroding after $24 \mathrm{~h}$.
\end{abstract}

Keywords: Corrosion protection, surface treatment, aluminum, hydrophobization, stearic acid

\section{INTRODUCTION}

Aluminum alloys are widely used as construction material in various fields of technology and life: in industrial and civil construction, for manufacture of carcasses of buildings, farms, window frames, ladders, in automotive industry, shipbuilding, in aero- and space engineering, in electrical engineering, in nuclear reactor construction etc. By the scale of application aluminium and its alloys occupy the second place after steel and cast iron [1-3].

Due to the presence of a natural thin oxide layer, the surface of aluminum and its alloys is quite stable to corrosion [4-7]. Because of it in some cases they are used without special anti-corrosion protection. However, due to the low thickness of aluminum's natural surface coating it often does not provide adequate protection from corrosion, for example, in a humid industrial atmosphere or seawater [8-10].

One of the recently taught after ways of protecting metal surfaces form aggressive environments is the formation of continuous coating layers on their surfaces with water-repellent properties and self-cleaning ability, which give the material superhydrophobic property and thus protect it from corrosion and contamination. In literature, superhydrophobic refers to surfaces on which the contact angle of a water droplet exceeds $150^{\circ}$ and the water droplet roles down with a tilt of less than $10^{\circ}$.

\section{EXPERIMENTAL MATERIALS}

For the application of conversion coatings, samples of an aluminum alloy 5556 , widely used in the automotive industry of the size of $30 \times 30 \times 1 \mathrm{~mm}$ were used. Solutions were prepared of pure and pro analysis grades of chemicals and distilled water. 
The preparation of samples and their hydrophobization are conducted the following way. The samples were degreased and washed in distilled water. Then the cleaned samples were subjected to etching for 10 seconds in a $100 \mathrm{~g} / \mathrm{L} \mathrm{NaOH}$ solution at room temperature with subsequent washing. Then the samples were immersed in a $\mathrm{HNO}_{3}$ solution for $1 \mathrm{~min}$. After that the aluminum samples were washed and immersed in hydrophobizing $0.01 \mathrm{M}$ solution of stearic acid (SA) with different dimethyl sulfoxide/water ratios $(1: 1,3: 1,5: 1,6: 1,7: 1,9: 1$, 1:0). The process is carried out at the solution temperature $\left(22-25^{\circ} \mathrm{C}\right)$ over the course of $10-15$ min at the temperature of $60-80^{\circ} \mathrm{C}$.

To accelerate the evaluation of the protective ability of conversion coatings, a drop-express method was used using an Akimov solution containing: $\mathrm{CuSO}_{4} \cdot 5 \mathrm{H}_{2} \mathrm{O} 82 \mathrm{~g} / \mathrm{l}, \mathrm{NaCl} 33 \mathrm{~g} / \mathrm{l}, 0.1 \mathrm{~N} \mathrm{HCl} 13 \mathrm{ml} / \mathrm{l}$. The PAA (Akimov's protective ability) of conversion coatings on aluminum or its alloys is estimated by this method as time (in seconds) before the color change at the surface under a drop from gray to black.

The thickness of the coatings was determined by ellipsometric method using the spectroscopic ellipsometer SENreseach 4.0 SER 800 with high-speed monochromator.

Surface roughness was studied with the OLYMPUS LEXT-OSL 4100 laser confocal microscope with MPLAPONLEXT 20 (x216) objective.

The contact angle of water during contact with the surface of the metal plates was measured on the Goniometer LK-1. The photos of drops were taken with the camera "Levenhuk C310 NG", and then the wetting angle was calculated using the DropShape software.

The durability of the hydrophobic coatings towards abrasion was studied on a modernized rotary abrasion meter Taber Elcometer 5135.

Corrosion tests were carried out in a salt fog chamber in accordance with the international standard ASTM B117. The protective ability of coatings was determined by trials of samples in salt fog chamber (Ascott S450iP). $5 \% \mathrm{NaCl}(\mathrm{pH} 6.5-7.2)$ was used as a saline solution which was sprayed as fog inside the chamber containing the samples. The trial was conducted at $t=35^{\circ} \mathrm{C}$ and humidity of $95-100 \%$. The inspection of the samples was conducted 3 times a day for the fixation of the formation time of the first corrosion hotbeds.

The preparation of samples and their hydrophobization are conducted the following way. The samples were degreased and washed in distilled water. Then the cleaned samples were subjected to etching for 10 seconds in a $100 \mathrm{~g} / \mathrm{L} \mathrm{NaOH}$ solution at room temperature with subsequent washing. Then the samples were immersed in a $\mathrm{HNO}_{3}$ solution for $1 \mathrm{~min}$. After that the aluminum samples were washed and immersed in hydrophobizing $0,01 \mathrm{M}$ solution of stearic acid with different dimethyl sulfoxide/water ratios $(1: 1,3: 1,5: 1,6: 1,7: 1,9: 1,1: 0)$. The process is carried out at the solution temperature $\left(22-25^{\circ} \mathrm{C}\right)$ over the course of $10-15 \mathrm{~min}$ at the temperature of $60-80^{\circ} \mathrm{C}$.

\section{EXPERIMENTAL}

Taking into account literary information and preliminary experiments a solution containing stearic acid was selected for research dimethyl sulfoxide (DMSO).

\subsection{Determination of the hydrophobic coatings depositing process parameters}

It was determined that range $2-3 \mathrm{~g} / \mathrm{L}$ of stearic acid is optimal, as since under these conditions a surface coating with the maximal contact angle $\theta_{\mathrm{c}}$ and protective ability is formed.

It was determined that the coating possesses the maximum contact angle $\left(\theta_{c}=130^{\circ}\right)$ and the maximum protective ability (PAA $=125 \mathrm{~s})$ at the dimethyl sulfoxide/water ratio of 7:1.

The influence of processing time and temperature of the working solution on the protective characteristics of coatings was studied, and it was determined that the surfaces with the maximal contact angle $\theta_{c}=141^{\circ}$ and 
with the maximal protective ability (142 s) form in $10-15 \mathrm{~min}$ of the process with the solution temperature of $30-40{ }^{\circ} \mathrm{C}$ (Figure 1).
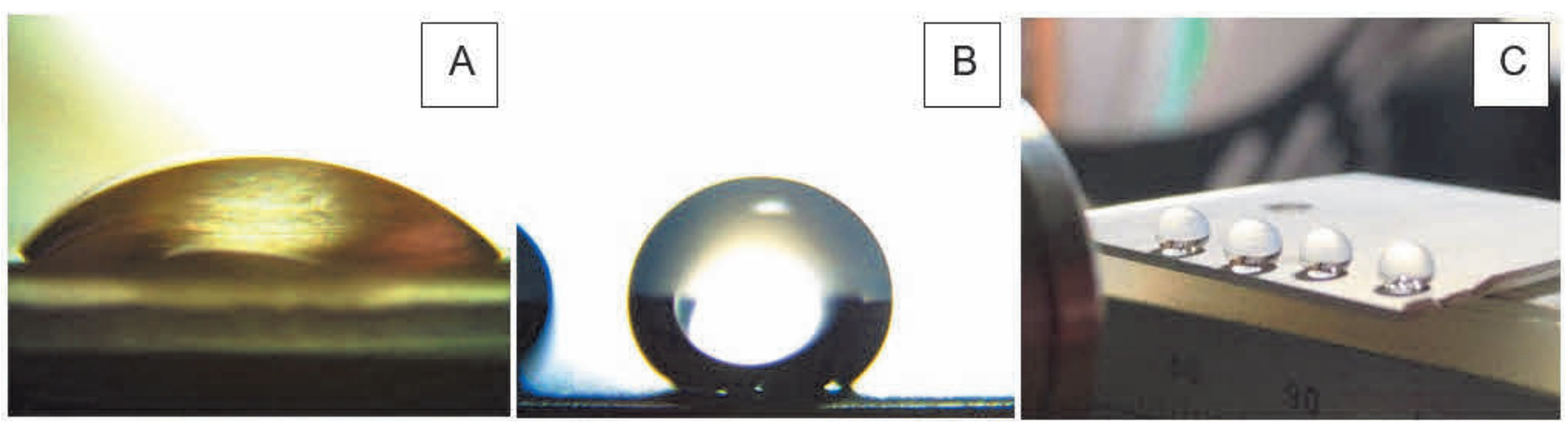

Figure 1 Photographs of water droplets on the surface of aluminium alloy $\left(A-\right.$ after degreasing AA $5556 \theta_{c}=$ $49^{\circ} ; \mathrm{B}, \mathrm{C}-$ after hydrophobization $\left(\theta_{\mathrm{c}}=141^{\circ}\right)$

Corrosion tests (ASTM B117) in salt fog chamber have shown that the developed coating with stands $82 \mathrm{~h}$ in salt fog $(5 \% \mathrm{NaCl})$ conditions until the appearance of the first corrosion hotbeds on the aluminum alloy, while the non-hydrophobizised alloy surface begins to corrode at $24 \mathrm{~h}$.

Using a spectroscopic ellipsometer it was determined that the thickness of the hydrophobic coating is 270 $300 \mathrm{~nm}$.

For the obtainment of coatings with high hydrophobic properties it is important to create the appropriate surface morphology, i.e. a surface with high roughness.

The influence of preliminary stages of preparation of the surface of the alloy AA5556 on its roughness (Table 1).

Table 1 Surface treatment stages

\begin{tabular}{|c|c|c|c|c|c|}
\hline \multirow[t]{2}{*}{ № } & \multirow{2}{*}{$\begin{array}{c}\text { Surface preparation } \\
\text { stage }\end{array}$} & \multirow[t]{2}{*}{ Composition of the solution } & \multirow[t]{2}{*}{ Process parameters } & \multicolumn{2}{|c|}{$\begin{array}{c}\text { Roughness } \\
\text { index }\end{array}$} \\
\hline & & & & $\mathrm{Ra}$ & $\mathbf{R z}$ \\
\hline 1 & Mechanical treatment & - & - & 0.762 & 5.528 \\
\hline 2 & Degreasing & $\begin{array}{c}\mathrm{Na}_{3} \mathrm{PO}_{4}{ }^{*} 12 \mathrm{H}_{2} \mathrm{O} 22 \mathrm{~g} / \mathrm{L} \\
\mathrm{Na}_{2} \mathrm{CO}_{3} 25 \mathrm{~g} / \mathrm{L} \\
\mathrm{NaOH} 7,5 \mathrm{~g} / \mathrm{L} \\
\text { Surfactant } 4 \mathrm{~g} / \mathrm{L} \\
\mathrm{Na}_{2} \mathrm{SiO}_{3} 10 \mathrm{~g} / \mathrm{L}\end{array}$ & $\begin{array}{c}\mathrm{t}=60^{\circ} \mathrm{C}-70{ }^{\circ} \mathrm{C} \\
\mathrm{pH}=11,1-11,7 \\
\text { process duration } 5-10 \\
\text { min }\end{array}$ & 0.838 & 6.885 \\
\hline 3 & Etching & $\mathrm{NaOH} 100 \mathrm{~g} / \mathrm{L}$ & $\begin{array}{c}\mathrm{t}=70^{\circ} \mathrm{C}-80^{\circ} \mathrm{C} \\
\text { process duration } 10 \mathrm{~s}\end{array}$ & 0.839 & 6.054 \\
\hline 4 & Lightening & $\begin{array}{c}\mathrm{HNO}_{3} 300 \mathrm{~g} / \mathrm{L} \\
\text { Conditions: process duration }=1 \\
\text { min }\end{array}$ & process duration $1 \mathrm{~min}$ & 0.782 & 6.258 \\
\hline 5 & Hydrophobization & $\begin{array}{c}\text { SA 2-3 g/L } \\
\text { DMSO/water ratio of 7:1 }\end{array}$ & $\begin{array}{c}\mathrm{t}=22^{\circ} \mathrm{C} \\
\text { process duration } 10 \mathrm{~min}\end{array}$ & 0.664 & 5.484 \\
\hline
\end{tabular}

As can be seen from the data in Table 1, the lightening stage lowers surface roughness, which subsequently negatively impacts the protective characteristics of hydrophobic surfaces. It was decided, that for subsequent studies it is necessary to exclude this stage. 
Table 2 The effect of the lightening stage on the surface roughness

\begin{tabular}{|l|c|c|}
\hline \multirow{2}{*}{} & \multicolumn{2}{|c|}{ Roughness index } \\
\cline { 2 - 3 } & $\mathrm{R}_{\mathrm{a}}$ & $\mathrm{R}_{\mathrm{z}}$ \\
\hline Hydrophobization (with lightening) & 0.664 & 5.484 \\
\hline Hydrophobization (without lightening) & 0.941 & 8.353 \\
\hline
\end{tabular}

I. e., by emmiting the lightening stage maximal roughness was achieved. As a result the contact angle of that surface was increased to $151^{\circ}$.

The parameter of the hydrophobic surface, that defines its abilily to self-clean, is the slip angle for a water droplet on its surface. With a high value of the slip angle the surface self-cleaning ability would be lower and thus the corrosion resistance would be lower as well. It was determined that the slip angle for the formation a superhydrophobic coating is $10^{\circ}$. For comparison, the slip angle of a non-hydrophobic alloy exceeds $100^{\circ}$.

\subsection{Tests of the coatings}

Corrosion tests of the AA 5556 samples in the salt fog chamber with the hydrophobic coating showed, that the developed coating exceeds $140 \mathrm{~h}$ in the salt fog $(5 \% \mathrm{NaCl})$ conditions before the formation of first corrosion hotbed in the base, while the untreated alloy begins corroding in $24 \mathrm{~h}$.

The change of the contact angle of the hydrophobized surface of the samples in relation to the duration of their time in the salt fog chamber was studied.

It was determined that after the exposure of the samples in a salt fog chamber for $45 \mathrm{~h}$, the surface still retains its superhydrophobic properties, while after $100 \mathrm{~h}$ the contact angle drops from $151^{\circ}$ to $95^{\circ}$ which indicates the degradation of the protective coating.

Along with this, the results of corrosion tests indicate that even if the coating loses its superhydrophobic properties, it still continuous to provide a high protection from corrosion for the alloy: the first base corrosion hotbed start appearing only after $140 \mathrm{~h}$.

\section{CONCLUSION}

A technological aluminium alloy surface hydrophobization process for the surface of the aluminium alloy, that allows to increase its surface corrosion stability and gives it self-cleaning ability was developed.

\section{ACKNOWLEDGEMENTS}

The reported study was supported by RFBR grant according to research project №17-03-00523.

\section{REFERENCES}

[1] KUZNETSOV, YU. I., SEMILETOV, A.M., CHIRKUNOV, A.A., ARKHIPUSHKIN, I.A., KAZANSKII, L.P. and ANDREEVA, N.P. Protecting Aluminum from Atmospheric Corrosion via Surface Hydrophobization with Stearic Acid and Trialkoxysilanes. Russian Journal of Physical Chemistry. 2018. vol. 92, no. 4, pp. 512-521.

[2] ZANG, D., ZHU, R., ZHANG, W., WU, J., YU, X. and ZHANG, Y. Stearic acid modified aluminum surfaces with controlled wetting properties and corrosion resistance. Corrosion Science. 2014. vol. 83, pp. 86-93.

[3] BOJNOVICH, L.B., EMEL'YANENKO, A.M. Gidrofobnye materialy i pokrytiya: principy sozdaniya, svojstva i primenenie. Uspekhi himii. 2008. vol. 77, no. 7, p. 619.

[4] ZHANG, D., WANG, L., QIAN, H. and LI,. X. Superhydrophobic surfaces for corrosion protection: a review of recent progresses and future directions. J. Coat. Technol. Res. 2016. vol. 13, no. 1, pp. 11-29. 
[5] FENG, L., ZHANG, YA., XI, J., ZHU, Y., WANG, N., XIA, F. AND JIANG, L. Petal Effect: A Superhydrophobic State with High Adhesive Force. Langmuir. 2008. vol. 24, no. 8, pp. 4114-4119.

[6] BALABANOV, V.I. Nanotekhnologii. Nauka budushchego. M. Eksmo. 2009. p.48.

[7] SEMILETOV, A.M., KUZNECOV, YU.I. and CHIRKUNOVA, A.A. Ingibirovanie atmosfernoj korrozii alyuminievogo splava AMg6 trialkoksisilanami i ih kompoziciyami s karboksilatami. Korroziya: materialy, zashchita. 2016. no. 6, pp. 29-36.

[8] SEMILETOV, A.M., KUZNECOV, YU.I. and CHIRKUNOVA, A.A. O gidrofobizacii poverhnosti splava AMg6 i zashchite ego ot atmosfernoj korrozii smesyami vysshih karboksilatov s trialkoksisilanami. Korroziya: materialy, zashchita. 2017. no. 6. pp. 24-30.

[9] SEMILETOV, A.M., KUZNECOV, YU.I. and CHIRKUNOVA, A.A. Modifikaciya poverhnosti splavov alyuminiya dvuhstadijnoj passivaciej rastvorami viniltrimetoksisilana i organicheskih ingibitorov. Korroziya: materialy, zashchita. 2018. no. 11, pp. 21-27.

[10] ANDREEVA, N.P., SEMILETOV, A.M., KUZNECOV, YU.I. and CHIRKUNOVA, A.A. Formirovanie passivnyh plenok na magnii v shchelochnyh rastvorah i adsorbciya na nih anionov organicheskih kislot. Korroziya: materialy, zashchita. 2017. no. 2. pp. 41-48. 